Bull. Chem. Soc. Ethiop. 2012, 26(1), 85-94.

ISSN 1011-3924

Printed in Ethiopia

DOI: http://dx.doi.org/10.4314/bcse.v26i1.9

(c) 2012 Chemical Society of Ethiopia

\title{
SYNTHESIS, CHARACTERIZATION AND THERMODYNAMIC STUDIES OF COMPLEXES OF DIMETHYL, DIETHYL, AND DIPHENYLTIN(IV) DICHLORIDES WITH (2H)-1,4-BENZOTHIAZINE-2,3-(4H)-DIONE DIOXIME
}

\author{
Abedien Zabardasti ${ }^{*}$, Ali Kakanejadifard and Leyla Shabani \\ Department of Chemistry, College of Sciences, Lorestan University, Khoramabad, Iran
}

(Received December 6, 2010; revised May 23, 2011)

\begin{abstract}
The diorganotin(IV) compounds, $\left[\mathrm{Me}_{2} \mathrm{SnCl}_{2}\left(\mathrm{H}_{2} \mathrm{~L}\right)\right],\left[\mathrm{Et}_{2} \mathrm{SnCl}_{2}\left(\mathrm{H}_{2} \mathrm{~L}\right)\right]$ and $\left[\mathrm{Ph}_{2} \mathrm{SnCl}_{2}\left(\mathrm{H}_{2} \mathrm{~L}\right)\right]\left(\mathrm{H}_{2} \mathrm{~L}\right.$ $=(2 \mathrm{H})-1,4-$ benzothiazine-2,3-(4H)-dione dioxime), were synthesized by treating the appropriate diorganotin(IV) dichloride with $\mathrm{H}_{2} \mathrm{~L}$ in anhydrous ethanol. These complexes were characterized by IR, MS, UV-Vis, and ${ }^{1} \mathrm{H}$ NMR. Thermodynamic studies of the reported complexes have been carried out and their stability were found in the order: $\left[\mathrm{Me}_{2} \mathrm{SnCl}_{2}\left(\mathrm{H}_{2} \mathrm{~L}\right)\right]>\left[\mathrm{Et}_{2} \mathrm{SnCl}_{2}\left(\mathrm{H}_{2} \mathrm{~L}\right)\right]>\left[\mathrm{Ph}_{2} \mathrm{SnCl}_{2}\left(\mathrm{H}_{2} \mathrm{~L}\right)\right]$. Theoretical calculations at the HF/3-21G* level showed that structures with alkyl groups at axial positions are more stable than their counterparts having alkyl groups at equatorial.
\end{abstract}

KEY WORDS: Diorganotin(IV) dichloride, vic-Dioxime, (2H)-1,4-Benzothiazine-2,3-(4H)-dionedioxime, Thermodynamic studies

\section{INTRODUCTION}

Organotin(IV) complexes have a wide range of applications such as PVC stabilizers [1], for chemical vapor decomposition (CVD) [2], in non-linear optics [3] and in catalyses [4-6]. Organotin complexes present innumerous pharmacological applications as antitumorals [7], antimicrobials [8, 9] and biocides [10] and locking agent in the formation of dinuclear complexes [11]. The cytotoxic activity of a variety of organotin complexes against tumor cell lines has been demonstrated [12, 13]. A considerable number of metal-based compounds, including many organotin derivatives have been synthesized and characterized in the search for compounds with greater antitumour activity and lower toxicity than platinum complexes. In recent years, investigations have been carried out to test the antitumor activity of organotin compounds. It has been observed that several di- and triorganotin(IV) species are active against various types of cancer [14-15]. Biological activity of organotin complexes is believed to be independent on the structure of molecule and coordination number of metal [16]. For compounds $\left[\mathrm{SnR}_{2} \mathrm{X}_{2}(\mathrm{LL})\right]$, where LL is an N,N-bidentate ligand, antitumour activity depends on the $\mathrm{Sn}-\mathrm{N}$ distances $(>2.39$ and $<2.39 \AA$ for the active and inactive compounds, respectively [17]), which suggests that dissociation of the ligand is a significant step in their mechanism of action.

In this work we used the ligand (2H)-1,4-benzothiazine-2,3-(4H)-dione dioxime, a potentially $\mathrm{N}, \mathrm{N}^{\prime}$-bidentate ligand $[18,19]$, for preparation of corresponding $\left[\mathrm{R}_{2} \mathrm{SnCl}_{2}\left(\mathrm{H}_{2} \mathrm{~L}\right)\right](\mathrm{R}$ $=\mathrm{Me}, \mathrm{Et}, \mathrm{Ph})$ complexes. Thermodynamic parameters for these adducts have been determined and also theoretical calculations were use for determination of more stable geometry.

\section{EXPERIMENTAL}

All the diorganotin(IV) compounds were purchased from Merck and were used as received. Solvents were dried before use according to literature [20].

*Corresponding author. E-mail: zebardasti.a@yahoo.com 
IR spectra were obtained in the KBr using a Perkin Elmer FT IR-1605 spectrophotometer. The ${ }^{1} \mathrm{H}$ and ${ }^{13} \mathrm{C}$ NMR spectra were recorded in a multinuclear Brucker DRX-500 AVANCE instrument at $500 \mathrm{MHz}$ and FT NMR 2.1 Materials $200 \mathrm{MHz}$ of JEOL. The NMR spectra were carried out in DMSO- $d_{6}$. Mass data was obtained on a Shimadzu GC-MS model QP5050 instrument.

Synthesis of (2E,3E)-2H-1,4-benzothiazine-2,3(4H)-dionedioxime $\left(\mathrm{H}_{2} \mathrm{~L}\right)$

To a stirring solution of 2-aminothiophenole $(1.38 \mathrm{~g}, 11 \mathrm{mmol})$ in absolute ethanol $20 \mathrm{~mL}$, a solution of dichloroglyoxime $(0.156 \mathrm{~g}, 1 \mathrm{mmol})$ in aqueous THF $(80 \%) 10 \mathrm{~mL}$ and $\mathrm{NaHCO}_{3}$ $0.05 \mathrm{~g}$ was added at room temperature. The solution was stirred for $4 \mathrm{~h}$, and then mixture was filtered. The filtrate was placed at room temperature for $24 \mathrm{~h}$. The gray precipitate was removed by filtration and precipitate was washed with cold THF. Recrystallization from 2-propanol gave gray crystals of $\mathrm{H}_{2} \mathrm{~L}$. Yield: $1.91 \mathrm{~g}, 91 \%$, m.p. $219-221{ }^{\circ} \mathrm{C}$. IR $(\mathrm{KBr}) \mathrm{cm}^{-1}$ : $3400(\mathrm{NH}), 2800-$ $3200(\mathrm{OH}), 1635$ and $1600(\mathrm{C}=\mathrm{N}) .{ }^{1} \mathrm{H}-\mathrm{NMR}$, ppm: $12.35\left(1 \mathrm{H}, \mathrm{OH}\right.$, exchangeable with $\left.\mathrm{D}_{2} \mathrm{O}\right)$, $10.76\left(1 \mathrm{H}, \mathrm{OH}\right.$, exchangeable with $\left.\mathrm{D}_{2} \mathrm{O}\right), 9.35$ (bs, $1 \mathrm{H}, \mathrm{NH}$, exchangeable with $\left.\mathrm{D}_{2} \mathrm{O}\right), 6.82-7.37$ $\left(4 \mathrm{H}, \mathrm{CH}_{\mathrm{Ar}}\right) .{ }^{13} \mathrm{C}-\mathrm{NMR}$, ppm: $137.56,137.24$ (oximic carbons $\mathrm{C} 2, \mathrm{C} 3$ ), 133.64, 126.97, 125.89, 120.97, 116.62, and 112.81 (aromatic ring). MS: m/z; $418(2 \mathrm{M}), 335,209\left(\mathrm{M}^{+}\right), 193$ and 150. Elemental analysis for $\mathrm{C}_{8} \mathrm{H}_{7} \mathrm{~N}_{3} \mathrm{O}_{2} \mathrm{~S}$ calculated: $\mathrm{C}, 45.93 ; \mathrm{H}, 3.37 ; \mathrm{N}, 20.08 ; \mathrm{S}, 15.32$; found: $\mathrm{C}$, 45.91; H, 3.37; N, 20.12; S, 15.30.

Synthesis of $\left[R_{2} \mathrm{SnCl}_{2}\left(\mathrm{H}_{2} L\right)\right]$ complex

To an ethanolic solution of $\mathrm{H}_{2} \mathrm{~L} 0.21 \mathrm{~g}$ ( $1 \mathrm{mmol}$, in EtOH $40 \mathrm{~mL}$ ) diorganotin(IV) dichloride (1 mmol, in EtOH $20 \mathrm{~mL}$ ) was added. The solution was stirred for $30 \mathrm{~min}$. The $\mathrm{pH}$ of the solution was kept around 4.5-5 by addition a solution of $\mathrm{NaOH}(0.01 \mathrm{M})$. The mixture was refluxed for 5 $\mathrm{h}$ at $60{ }^{\circ} \mathrm{C}$, volume of the solution reduced to $15 \mathrm{~mL}$ by reduced pressure distillation. The precipitate was filtered and washed with $\mathrm{H}_{2} \mathrm{O}, \mathrm{Et}_{2} \mathrm{O}$ and hot $\mathrm{EtOH}$.

$\left[\mathrm{Me}_{2} \mathrm{SnCl}_{2}\left(\mathrm{H}_{2} \mathrm{~L}\right)\right] .0 .23 \mathrm{~g}(54 \%), 246.5{ }^{\circ} \mathrm{C}$ (decomposed), ${ }^{1} \mathrm{H}$ NMR, IR (KBr, $\left.\mathrm{cm}^{-1}\right)$ and EI-MS $(\mathrm{m} / \mathrm{z})$ data were given in Tables 2 and 3. Elemental analysis for $\mathrm{C}_{10} \mathrm{H}_{13} \mathrm{Cl}_{2} \mathrm{~N}_{3} \mathrm{O}_{2} \mathrm{SSn}$ calculated: C, 28.00; H, 3.06; N, 9.80; found: C, 27.83; H, 3.01; N, 9.62. EI-MS (m/z): 429.

[Et $\left.\mathrm{SnCl}_{2}\left(\mathrm{H}_{2} \mathrm{~L}\right)\right] .0 .26 \mathrm{~g}(57 \%)$, m.p. $252{ }^{\circ} \mathrm{C},{ }^{1} \mathrm{H}$ NMR, IR $\left(\mathrm{KBr}, \mathrm{cm}^{-1}\right)$ and EI-MS (m/z) data were given in Tables 2 and 3. Elemental analysis for $\mathrm{C}_{12} \mathrm{H}_{17} \mathrm{Cl}_{2} \mathrm{~N}_{3} \mathrm{O}_{2} \mathrm{SSn}$ calculated: $\mathrm{C}$, 31.54; $\mathrm{H}$, 3.75; N, 9.20; found: C, 31.14; H, 3.64; N, 8.96. EI-MS (m/z): 457.

[Ph $\left.\mathrm{SnCl}_{2}\left(\mathrm{H}_{2} \mathrm{~L}\right)\right] .0 .30 \mathrm{~g}(57 \%), 294.5{ }^{\circ} \mathrm{C}$ (decomposed), ${ }^{1} \mathrm{H}$ NMR, IR $\left(\mathrm{KBr}, \mathrm{cm}^{-1}\right)$ and EI-MS $(\mathrm{m} / \mathrm{z})$ data were given in Tables 2 and 3. Elemental analysis for $\mathrm{C}_{20} \mathrm{H}_{17} \mathrm{Cl}_{2} \mathrm{~N}_{3} \mathrm{O}_{2} \mathrm{SSn}$ calculated: C, 43.44; H, 3.10; N, 7.60; found: C, 43.03; H, 3.01; N, 7.20. EI-MS (m/z): 553.

\section{Solution studies}

UV-Vis measurements were carried out by a titration method at $5,10,15,20$, and $25 \pm 1{ }^{\circ} \mathrm{C}$, in duplicate experiments. In a typical measurement, $2.0 \mathrm{~mL}$ solution of $\mathrm{H}_{2} \mathrm{~L}\left(1 \times 10^{-4} \mathrm{M}\right)$ in DMF was titrated by $\mathrm{Me}_{2} \mathrm{SnCl}_{2}\left(3.2 \times 10^{-3} \mathrm{M}\right)$. UV-Vis spectrum was recorded over a range of 260$510 \mathrm{~nm}$ and formation constant $\mathrm{K}\left(\mathrm{M}^{-2}\right)$ of the complexes were calculated by the SQUAD program [21]. This program is designed to calculate the best values for the stability constants of the proposed equilibrium model by employing a non-linear least-squares approach. 
$X$-ray structure analysis of $\mathrm{H}_{2} \mathrm{~L}$

The structure of compound $\left(\mathrm{H}_{2} \mathrm{~L}\right)$ was established by X-ray crystallography (see Figure 1, Table 1 and also experimental section for details). There are some unusual structural features for $\mathrm{H}_{2} \mathrm{~L}$.

Table 1. Crystal and structure refinement for (2E,3E)-2H-1,4-dibenzothiazine-2,3 (4H)-dione dioxime.

\begin{tabular}{|l|l|}
\hline Formula & $\mathrm{C}_{8} \mathrm{H}_{11} \mathrm{~N}_{3} \mathrm{O}_{4} \mathrm{~S}$ \\
\hline Formula weight & 209 \\
\hline Temperature & $120(2) \mathrm{K}$ \\
\hline Wavelength & $0.71073 \AA$ \\
\hline Crystal system, space group & Orthorhombic, Pbca \\
\hline Unit cell dimensions & $\mathrm{a}=9.1636(18) \AA \quad \alpha=90^{\circ} \mathrm{b}=9.8195(18) \AA$ \\
& $\beta=90^{\circ} \quad \mathrm{c}=24.165(4) \AA \quad \gamma=90^{\circ}$ \\
\hline V & $2174.4(7) \AA^{3}$ \\
\hline Z, Calculated density & $8,1.498 \mathrm{mg}^{3} / \mathrm{m}^{3}$ \\
\hline Absorption coefficient & $0.302 \mathrm{~mm}^{-1}$ \\
\hline F(000) & 1024 \\
\hline Crystal size & $0.5 \times 0.5 \times 0.1 \mathrm{~mm}^{3}$ \\
\hline Theta range for data collection & 1.69 to $27.04^{\circ}$ \\
\hline Index ranges & $-11<=\mathrm{h}<=11,-12<=\mathrm{k}<=12,-30<=1<=28$ \\
\hline Reflections collected & 15018 \\
\hline Independent reflections & $2337[\mathrm{R}($ int $)=0.0823]$ \\
\hline Completeness to theta & $27.04^{\circ}, 97.8 \%$ \\
\hline Absorption correction & $\mathrm{Semi}-\mathrm{empirical}$ from equivalents \\
\hline Refinement method & Full-matrix least-squares on $\mathrm{F}^{2}$ \\
\hline Data/restraints/parameters & $2337 / 0 / 145$ \\
\hline Goodness-of-fit on $\mathrm{F}^{2}$ & 1.018 \\
\hline Final R indices for 1482 refl. with $[\mathrm{I}>2 \mathrm{Sigma}(\mathrm{I})]$ & $\mathrm{R} 1=0.0458, \mathrm{wR} 2=0.0962$ \\
\hline R indices (all data) & $\mathrm{R} 1=0.0850, \mathrm{wR} 2=0.1072$ \\
\hline Largest diff. peak and hole & 0.433 and -0.251 e $\AA^{-3}$ \\
\hline & \\
\hline
\end{tabular}

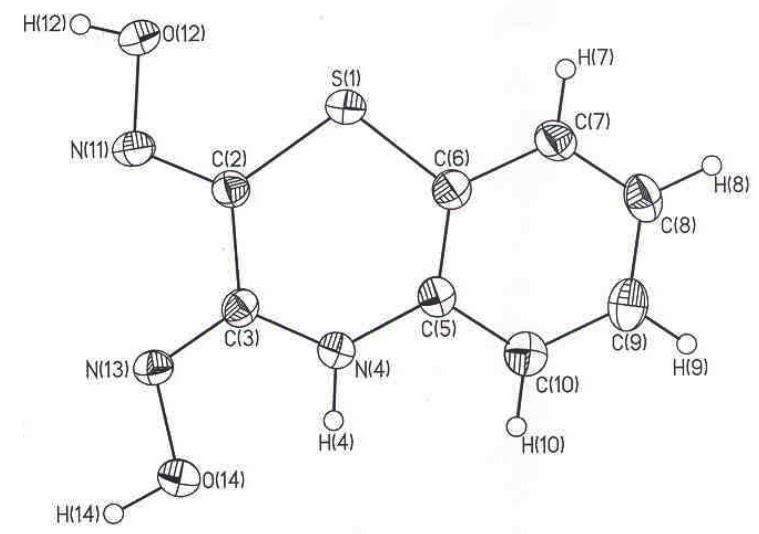

Figure 1. ORTEP drawing of $\mathrm{H}_{2} \mathrm{~L}$. 
The clear colorless crystal with the dimensions $0.5 \times 0.5 \times 0.1 \mathrm{~mm}^{3}$ was used for data collection on a Bruker SMART $1000 \mathrm{CCD}$ diffractommeter with graphite monochromated $\operatorname{MoK} \alpha(\lambda=0.71073 \AA) . \mathrm{C}_{8} \mathrm{H}_{11} \mathrm{~N}_{3} \mathrm{O}_{4} \mathrm{~S}, \mathrm{FW}=245.26$. Orthorhombic crystals in a Pbca Space group, $a=9.1636(18) \AA, b=9.8195(18) \AA, c=24.165(4) \AA, \beta=93.08(1)^{\circ}, V=1284.07(16) \AA^{-}$ ${ }^{3} . \mathrm{Z}=8, \mathrm{D}(\mathrm{X}$-ray, calcd $)=1.498 \mathrm{Mg} / \mathrm{m}^{3} . \mu=0.302 \mathrm{~mm}^{-1}, \mathrm{~F}(000)=1024, \mathrm{~T}=120(2)^{\circ} \mathrm{K}$. Of the 15018 total reflections, 2337 were unique. $\mathrm{R}_{\text {int }}=0.0823$. The structure was dissolved by direct methods (SHELEXTL PC) [22] and refined by full-matrix leaste-squares (isotropic refinement of the molecule and location of remaining non-hydrogen atoms from a difference Fourrier and subsequent anisotropic refinement on all atoms; $\mathrm{H}$ atoms were found after highangle refinement in a difference Fourrier and their positions included in the final stages of refinement), factors of $\mathrm{R} 1=0.0458$, Rw $2=0.0962$ for 1482 unique observed reflections (another reflections, with $\mathrm{I}>2 \sigma(\mathrm{I})$, were considered unobserved). No significant features, only

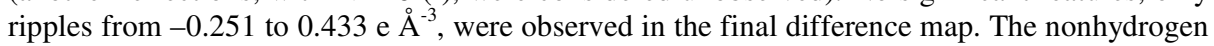
atoms were refined anisotropically.

Torsion angles for $\mathrm{N}_{4}-\mathrm{C}_{5}-\mathrm{C}_{6}-\mathrm{S}_{1}, \mathrm{C}_{5}-\mathrm{C}_{6}-\mathrm{N}_{4}-\mathrm{C}_{3}$ and $\mathrm{C}_{5}-\mathrm{C}_{6}-\mathrm{S}_{1}-\mathrm{C}_{2}$ are $-2.1^{\circ}, 3.4^{\circ}$ and $-7.6^{\circ}$, respectively, which they show that the thiazine ring is slightly moved from planarity with respect to the fused aromatic ring. Results show a resonance between aromatic ring and $\mathrm{C}=\mathrm{N}$ bonds of oxime, in which $\mathrm{N}$ and $\mathrm{S}$ atoms of the $\mathrm{H}_{2} \mathrm{~L}$ have been included in this resonance. This can be attributed to the influence of bond lengths, bond angles, pyramid and planarity of thiazine ring. The torsion angles of $\mathrm{N}_{13}-\mathrm{C}_{3}-\mathrm{C}_{2}-\mathrm{N}_{11}, \mathrm{~N}_{4}-\mathrm{C}_{3}-\mathrm{C}_{2}-\mathrm{S}_{1}$, and $\mathrm{C}_{6}-\mathrm{C}_{5}-\mathrm{C}_{2}-\mathrm{C}_{3}$ are $-16.8(3)^{\circ}$, $-19.9^{\circ}$ and $9.93(18)^{\circ}$, respectively. These data show that $\mathrm{C}_{2}$ and $\mathrm{C}_{3}$ are not coplanar and the $\mathrm{C}_{2^{-}}$ $\mathrm{C}_{3}$ bond shows a single bond characteristic.

Furthermore, the X-ray data showed that molecule $\mathrm{H}_{2} \mathrm{~L}$ could be existed as a dimmer through intermolecular hydrogen bond formation. The unit cell of the resulting crystal clearly revealed that a three dimensional network is formed owing to the presence of intermolecular hydrogen bond interaction. The hydrogen bonding in $\mathrm{H}_{2} \mathrm{~L}$ leads to a face-to-edge [23] configuration which is supported by two lattice water molecules.

The experimental data and structural models show the existence of three possible cyclic configurations for vic-dioximes (anti, amphi and syn), Scheme 1. The isomer distribution depends on steric effects of substitutions and the possibility of hydrogen bond formation between the oxime groups. The torsion angles of molecule $\mathrm{H}_{2} \mathrm{~L}, \mathrm{~N}_{11}-\mathrm{C}_{2}-\mathrm{C}_{3}-\mathrm{N}_{13}, \mathrm{C}_{2}-\mathrm{C}_{3}-\mathrm{N}_{13}-\mathrm{O}_{14}$, $\mathrm{N}_{4}-\mathrm{C}_{3}-\mathrm{C}_{2}-\mathrm{S}_{1}$ and $\mathrm{C}_{3}-\mathrm{C}_{2}-\mathrm{N}_{11}-\mathrm{O}_{12}$ confirm an anti configuration and the oxime groups will not be coplanar unless they are linked by a hydrogen bond. Also mass spectrum of $\mathrm{H}_{2} \mathrm{~L}$ shows a molecular ion peak at $418 \mathrm{~m} / \mathrm{z}$ which confirm its dimmer structure that arise hydrogen bonding. Atomic coordinate, temperature factors, bond distances, bond angles and torsion have been deposited at the Cambridge Crystallographic Data Center. Number CCDC 299488. These data can be obtained free of charge via WWW.ccdc.cam.ac.uk/conts/retrieving; html (or from Cambridge Crystallographic Data Center; deposit@ccdc.cam.ac.uk).

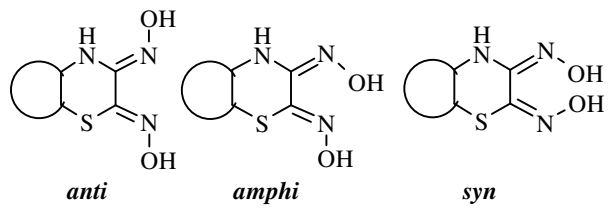

Scheme 1. Possible isomer of cyclic vic-dioximes [24]. 


\section{RESULTS AND DISCUSSION}

Reaction of diorganotin(IV) dichlorides with $\mathrm{H}_{2} \mathrm{~L}$ led to formation of $\left[\mathrm{R}_{2} \mathrm{SnCl}_{2}\left(\mathrm{H}_{2} \mathrm{~L}\right)\right]$ complexes in yields of $54-57 \%$ (Scheme 2). Products were characterized by means of FT-IR, ${ }^{1} \mathrm{H}$ NMR, EI-MS, and mole ratio determination using UV-Vis electronic absorption methods, (Figure 2). The results obtained through these techniques are in agreement with the proposed 1:1 stoichometry between the organotin moieties and the vic-dioxime ligand. Due to the low solubility of these complexes, our attempts were failed to get single crystals suitable for X-ray crystallographic.

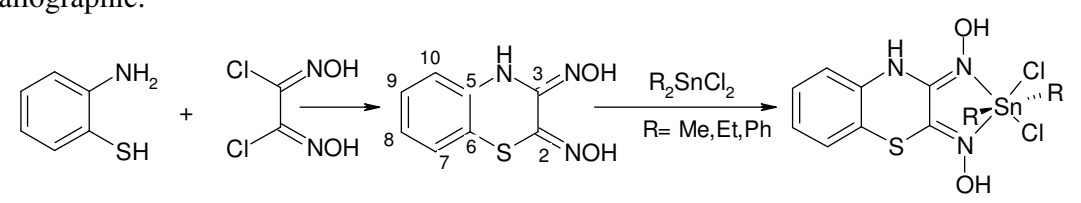

Scheme 2
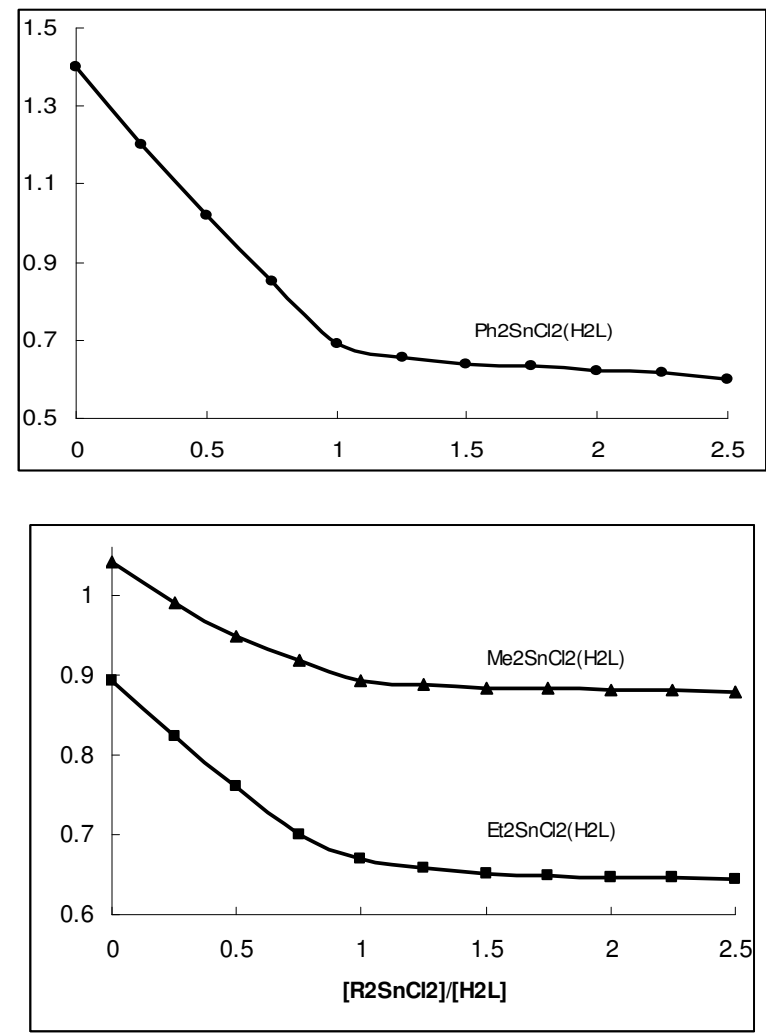

Figure 2. Absorbance versus mole ratio plots for titration of $\mathrm{H}_{2} \mathrm{~L}$ with $\mathrm{R}_{2} \mathrm{SnCl}_{2}$ $\left(\left[\mathrm{Me}_{2} \mathrm{SnCl}_{2}\left(\mathrm{H}_{2} \mathrm{~L}\right)\right]\right.$ at $277,\left[\mathrm{Et}_{2} \mathrm{SnCl}_{2}\left(\mathrm{H}_{2} \mathrm{~L}\right)\right]$ at 310 and $\left[\mathrm{Ph}_{2} \mathrm{SnCl}_{2}\left(\mathrm{H}_{2} \mathrm{~L}\right)\right]$ at $308 \mathrm{~nm}$ ). 


\section{${ }^{1}$ H NMR spectral analysis}

The ${ }^{1} \mathrm{H}$ NMR data for the $\mathrm{H}_{2} \mathrm{~L}$ and its complexes with diorganotin(IV) dichlorides are given in Table 2. The ${ }^{1} \mathrm{H}$ NMR spectrum of $\mathrm{H}_{2} \mathrm{~L}$ is characterized by four signals at $12.34,10.76,9.36$ and 6.83-7.38 ppm, which are assigned to the protons associated with $-\mathrm{OH},-\mathrm{OH},-\mathrm{NH}$ and aromatic ring protons, respectively. The $\mathrm{OH}$ protons of the ligand are magnetically nonequivalent thus they give two single resonances at $\delta 12.34$ and $10.76 \mathrm{ppm}$. In ${ }^{1} \mathrm{H}$ NMR spectra of $\left[\mathrm{R}_{2} \mathrm{SnCl}_{2}\left(\mathrm{H}_{2} \mathrm{~L}\right)\right]$ complexes the signals of $\mathrm{OH}$ protons are seen at 12.39 and $10.79 \mathrm{ppm}$ for $\mathrm{Me}_{2} \mathrm{SnCl}_{2}\left(\mathrm{H}_{2} \mathrm{~L}\right), 12.38$ and $10.80 \mathrm{ppm}$ for $\mathrm{Et}_{2} \mathrm{SnCl}_{2}\left(\mathrm{H}_{2} \mathrm{~L}\right)$ and $\mathrm{Ph}_{2} \mathrm{SnCl}_{2}\left(\mathrm{H}_{2} \mathrm{~L}\right)$ complexes. Also, the $\mathrm{NH}$ proton of $\mathrm{H}_{2} \mathrm{~L}$ is appeared at 9.36 that shifted downfield to $9.44 \mathrm{ppm}$ in $\mathrm{Me}_{2} \mathrm{SnCl}_{2}\left(\mathrm{H}_{2} \mathrm{~L}\right)$, and $9.40 \mathrm{ppm}$ for $\mathrm{Et}_{2} \mathrm{SnCl}_{2}\left(\mathrm{H}_{2} \mathrm{~L}\right)$ and $\mathrm{Ph}_{2} \mathrm{SnCl}_{2}\left(\mathrm{H}_{2} \mathrm{~L}\right)$ complexes. The aromatic protons of the $\mathrm{H}_{2} \mathrm{~L}$ (6.83-738 ppm) shifted slightly downfield (6.90-7.45 ppm) upon complex formation. The magnitude of ${ }^{2} \mathbf{J}\left({ }^{119} \mathrm{Sn}-\mathrm{H}\right)$ for five to six or seven coordinated dimethyltin(IV) complex has been reported in the range of 71-116 Hz depending on the stereochemistry of tin and the nature of the ligand [25]. Various kinds of protons in $\left[\mathrm{R}_{2} \mathrm{SnCl}_{2}\left(\mathrm{H}_{2} \mathrm{~L}\right)\right]$ complexes have been identified and total numbers of protons estimated from the integration curves of ${ }^{1} \mathrm{H}$ NMR spectra are in agreement with the proposed molecular formula. The sharp signal attributed to the methyl group of $\left(\mathrm{CH}_{3}\right)_{2} \mathrm{SnCl}_{2}\left(\mathrm{H}_{2} \mathrm{~L}\right)$ appeared as a singlet at $1.06 \mathrm{ppm}$ and the ${ }^{2} \mathrm{~J}\left({ }^{119} \mathrm{Sn}-\mathrm{H}\right)$ and ${ }^{2} \mathrm{~J}\left({ }^{117} \mathrm{Sn}-\mathrm{H}\right)$ coupling constant values are $77 \mathrm{~Hz}$ and $73 \mathrm{~Hz}$, which are almost similar with the coupling constant previously reported for six coordinated tin complexes. In the complex $\left(\mathrm{CH}_{3} \mathrm{CH}_{2}\right)_{2} \mathrm{SnCl}_{2}\left(\mathrm{H}_{2} \mathrm{~L}\right)$ a triplet at $1.27-1.30 \mathrm{ppm}$ for $\mathrm{CH}_{3}$ and a quartet at 1.53-1.58 ppm for $\mathrm{CH}_{2}$ are assigned to ethyl group of complex. $\left(\mathrm{C}_{6} \mathrm{H}_{5}\right)_{2} \mathrm{SnCl}_{2}\left(\mathrm{H}_{2} \mathrm{~L}\right)$ showed a multiplet in the region 6.86-7.44 ppm, which may be assigned to aromatic ring protons of $\mathrm{H}_{2} \mathrm{~L}$ and $\mathrm{Sn}-\mathrm{Ph}$ protons. The signals could not properly assign due to overlap of corresponding signals of $\mathrm{Ph}-\mathrm{Sn}$ and aromatic ring protons.

Table 2. ${ }^{1} \mathrm{H}$ NMR chemical shift ( $\left.\delta / \mathrm{ppm}\right)$ of $\mathrm{H}_{2} \mathrm{~L}$ and its complexes with $\mathrm{R}_{2} \mathrm{SnCl}_{2}$.

\begin{tabular}{|l|l|l|l|l|}
\hline \multicolumn{3}{|c|}{ Compound } & \multirow{2}{*}{ Proton } \\
\cline { 1 - 4 } $\mathrm{Ph}_{2} \mathrm{SnCl}_{2}\left(\mathrm{H}_{2} \mathrm{~L}\right)$ & $\mathrm{Et}_{2} \mathrm{SnCl}_{2}\left(\mathrm{H}_{2} \mathrm{~L}\right)$ & $\mathrm{Me}_{2} \mathrm{SnCl}_{2}\left(\mathrm{H}_{2} \mathrm{~L}\right)$ & $\mathrm{H}_{2} \mathrm{~L}$ & \\
\hline $12.38(\mathrm{~s})$ & $12.38(\mathrm{~s})$ & $12.39(\mathrm{~s})$ & $12.34(\mathrm{~s})$ & $\mathrm{H} 21(\mathrm{OH})$ \\
\hline $10.80(\mathrm{~s})$ & $10.80(\mathrm{~s})$ & $10.79(\mathrm{~s})$ & $10.76(\mathrm{~s})$ & $\mathrm{H} 20(\mathrm{OH})$ \\
\hline $9.40(\mathrm{~s})$ & $9.40(\mathrm{~s})$ & $9.44(\mathrm{~s})$ & $9.36(\mathrm{~s})$ & $\mathrm{H} 18(\mathrm{NH})$ \\
\hline $6.86-7.44(\mathrm{~m})$ & $7.39-7.41(\mathrm{~d})$ & $7.43-7.45(\mathrm{~d})$ & $7.37-7.38(\mathrm{~d}, \mathrm{~J}=8.11)$ & $\mathrm{H} 7$ \\
\hline $6.86-7.44(\mathrm{~m})$ & $7.21-7.22(\mathrm{~d})$ & $7.24-7.25(\mathrm{~d})$ & $7.18-7.19(\mathrm{~d}, \mathrm{~J}=7.84)$ & $\mathrm{H} 10$ \\
\hline $6.86-7.44(\mathrm{~m})$ & $7.10-7.13(\mathrm{t})$ & $7.12-7.15(\mathrm{t})$ & $7.07-7.10(\mathrm{t}, \mathrm{J}=7.5)$ & $\mathrm{H} 8$ \\
\hline $6.86-7.44(\mathrm{~m})$ & $6.86-6.89(\mathrm{t})$ & $6.90-6.92(\mathrm{t})$ & $6.83-6.86(\mathrm{t}, \mathrm{J}=7.44)$ & $\mathrm{H} 9$ \\
\hline $6.86-7.44(\mathrm{~m})$ & $1.27-1.30(\mathrm{t}), 1.53-1.58(\mathrm{q})$ & $1.06(\mathrm{t})$ & - & $\mathrm{Me}-$, Et-, $\mathrm{Ph}-$ \\
\hline
\end{tabular}

\section{Infrared spectral analysis}

The IR data for the ligand $\mathrm{H}_{2} \mathrm{~L}$ and its complexes are given in Table 3. The free ligand exhibiting characteristic $v_{(\mathrm{N}-\mathrm{O})}, v_{(\mathrm{C}=\mathrm{N})}, v_{(\mathrm{OH})}$, and $v_{(\mathrm{NH})}$ bands at $920,1635,2800-3200$ and 3400 $\mathrm{cm}^{-1}$, respectively. All these band absorptions were seen in the complexes but some of them shifted with respect to free $\mathrm{H}_{2} \mathrm{~L}$. The stretching vibration of $\mathrm{N}-\mathrm{O}$ observed at $920 \mathrm{~cm}^{-1}$ in $\mathrm{H}_{2} \mathrm{~L}$ is shifted to the higher region at $922-945 \mathrm{~cm}^{-1}$ in the complexes supporting that oxime $\mathrm{N}$ atoms are coordinated to $\mathrm{Sn}(\mathrm{IV})$. In the $440-480 \mathrm{~cm}^{-1}$ region of infrared spectra of complexes some bands appeared for Sn-N stretching vibration [26]. The intense band observed at $1635 \mathrm{~cm}^{-1}$ in the $\mathrm{H}_{2} \mathrm{~L}$ attributed due to imine $\mathrm{C}=\mathrm{N}$ appears at $1645-1649 \mathrm{~cm}^{-1}$ in the IR spectra of complexes. Also band characteristic of the $\mathrm{NH}$ and the $\mathrm{OH}$ stretching frequencies are remained and appeared at $3120-3400 \mathrm{~cm}^{-1}$ in the complexes. 
Table 3. Vibrational sterching frequencies $\left(\mathrm{cm}^{-1}\right)$ of $\mathrm{H}_{2} \mathrm{~L}$ and its complexes with $\mathrm{R}_{2} \mathrm{SnCl}_{2}$.

\begin{tabular}{|l|c|c|c|c|c|c|c|}
\hline Compound & $v_{(\mathrm{N}-\mathrm{O})}$ & $v_{(\mathrm{C}-\mathrm{C})}$ Oxime & $v_{(\mathrm{C}=\mathrm{N})}$ & $v_{(\mathrm{C}-\mathrm{H})}$ Aliph & $v_{(\mathrm{C}-\mathrm{H})}$ Arom & $v_{(\mathrm{OH})}$ & $v_{(\mathrm{NH})}$ \\
\hline $\mathrm{H}_{2} \mathrm{~L}$ & 920 & 1600,1420 & 1635 & - & 3100 & $2800-3200$ & 3400 \\
\hline $\mathrm{Me}_{2} \mathrm{SnCl}_{2}\left(\mathrm{H}_{2} \mathrm{~L}\right)$ & 934 & 1593,1437 & 1649 & $2800-2930$ & 3095 & $3120-3330$ & 3331 \\
\hline $\mathrm{Et}_{2} \mathrm{SnCl}_{2}\left(\mathrm{H}_{2} \mathrm{~L}\right)$ & 945 & 1592,1432 & 1646 & $2800-2950$ & 3110 & $3240-3390$ & 3391 \\
\hline $\mathrm{Ph}_{2} \mathrm{SnCl}_{2}\left(\mathrm{H}_{2} \mathrm{~L}\right)$ & 922 & 1590,1428 & 1645 & - & 3116 & $3125-3341$ & 3338 \\
\hline
\end{tabular}

\section{EI-MS spectral analysis}

In the EI-MS spectrum a molecular ion peak appeared at 429 for $\mathrm{Me}_{2} \mathrm{SnCl}_{2}\left(\mathrm{H}_{2} \mathrm{~L}\right)$. By fragmentation some peaks have been appeared at 404, 392, 374, 374, 362, 352, 331, 322, 298, 276 , and 268. The parent molecular ion peak and its related fragments are in a good agreement with our proposed structure.

The EI-MS spectrum of $\mathrm{Et}_{2} \mathrm{SnCl}_{2}\left(\mathrm{H}_{2} \mathrm{~L}\right)$ showed a molecular ion peak at 457 and some fragments at 442, 427, 411, 396, 384, 365, 344, 322, 304, and 290. These fragments confirm our proposed structure for this complex. Similarly, The presence of a molecular ion peak at 553 and some other peaks at 507, 486, 449, 430, 395, 373, 298, 282, 266, 248, and 191 in the mass spectrum of $\mathrm{Ph}_{2} \mathrm{SnCl}_{2}\left(\mathrm{H}_{2} \mathrm{~L}\right)$, confirms our considered structure for this complex.

\section{Thermodynamic studies}

Interactions of diorganotin(IV) dichlorides with $\mathrm{H}_{2} \mathrm{~L}$ were studied by means of UV-Vis titration. By addition of diorganotin(IV) dichlorides to a solution of $\mathrm{H}_{2} \mathrm{~L}$, the original band of $\mathrm{H}_{2} \mathrm{~L}$ (260$\left.370, \lambda_{\max } 278 \mathrm{~nm}\right)$ was weakened. In contrast, a new weak band was appeared at $\left(380-430, \lambda_{\max }\right.$ $417 \mathrm{~nm}$ ) for the complex.

The occurrence of isosbestic points during a reaction is very informative. Isosbestic points are wavelengths at which the absorbance remains constant as the reactant and product composition changes. Isobesdic point suggests that the molecule exists as Zwitter ion, in the case of complex it is indicative of the formation of only one product. The occurrence of isosbestic points implies the absence of appreciable amount of reaction intermediates. Also it has been mentioned in the literature that the presence of isosbestic points means that the complex forms through equilibrium reactions [14]. Therefore, a clear isosbestic point at $357 \mathrm{~nm}$ for this interaction (Figure 3) represents a reversible complex formation in solution. The molar ratio plots are indicating 1:1 stoichimetry for these complexes (Figure 2).

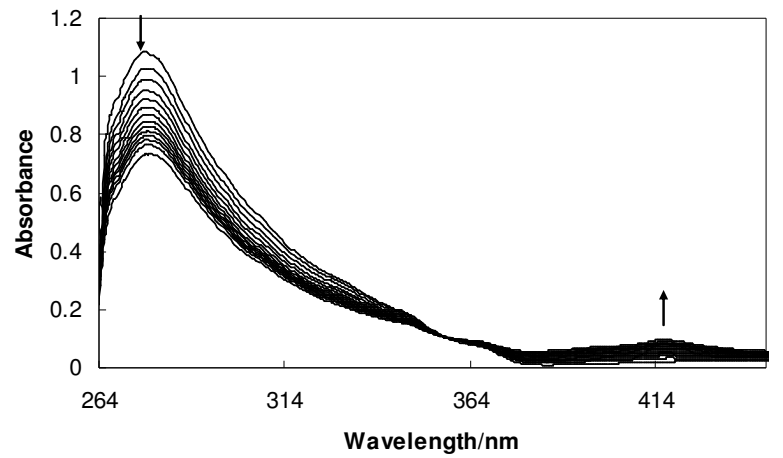

Figure 3. Titration spectrum of $\mathrm{H}_{2} \mathrm{~L}$ with $\mathrm{Me}_{2} \mathrm{SnCl}_{2}$ in DMF, $\left[\mathrm{Me}_{2} \mathrm{SnCl}_{2}\left(\mathrm{H}_{2} \mathrm{~L}\right)\right]$, isosbestic point at $357 \mathrm{~nm}$. 
The thermodynamic parameters are useful tools for studying these reactions and understanding the charactristic of corresponding complexes. The formation constant $K\left(\mathrm{M}^{-1}\right)$ of complexes was determined at several temperatures by analyzing the concentration and temperature dependence of the UV-Vis absorbtion by a SQUAD program (Table 4). Van't Hoff plots of these formation constants, $K\left(\mathrm{M}^{-1}\right)$, lead to other thermodynamic parameters, $\Delta H^{\circ}, \Delta S^{\circ}$, and $\Delta G^{\circ}$ (Table 4).

Table 4. The formation constants $(\log \mathrm{K})$ for $\left[\mathrm{R}_{2} \mathrm{SnCl}_{2}\left(\mathrm{H}_{2} \mathrm{~L}\right)\right]$ complexes.

\begin{tabular}{|l|c|c|c|c|l|}
\hline \multirow{2}{*}{ Complex } & \multicolumn{5}{|c|}{ Temp. $\left({ }^{\circ} \mathrm{C}\right)$} \\
\cline { 2 - 6 } & 10 & 15 & 20 & 25 & 30 \\
\hline $\mathrm{Me}_{2} \mathrm{SnCl}_{2}\left(\mathrm{H}_{2} \mathrm{~L}\right)$ & $4.25 \pm 0.02$ & $3.93 \pm 0.04$ & $3.46 \pm 0.02$ & $3.18 \pm 0.01$ & $2.85 \pm 0.02$ \\
\hline $\mathrm{Et}_{2} \mathrm{SnCl}_{2}\left(\mathrm{H}_{2} \mathrm{~L}\right)$ & $3.67 \pm 0.01$ & $3.23 \pm 0.03$ & $2.91 \pm 0.06$ & $2.67 \pm 0.02$ & $2.32 \pm 0.03$ \\
\hline $\mathrm{Ph}_{2} \mathrm{SnCl}_{2}\left(\mathrm{H}_{2} \mathrm{~L}\right)$ & $3.19 \pm 0.02$ & $2.94 \pm 0.01$ & $2.64 \pm 0.02$ & $2.21 \pm 0.04$ & $1.96 \pm 0.02$ \\
\hline
\end{tabular}

Table 5. The thermodynamic parameters for $\left[\mathrm{R}_{2} \mathrm{SnCl}_{2}\left(\mathrm{H}_{2} \mathrm{~L}\right)\right]$ complexes.

\begin{tabular}{|l|c|c|c|}
\hline Complex & $-\Delta \mathrm{H}^{\circ}\left(\mathrm{kcal} \mathrm{mol}^{-1}\right)$ & $-\Delta \mathrm{S}^{\circ}\left(\mathrm{cal} \mathrm{mol}^{-1} \mathrm{~K}^{-1}\right)$ & $-\Delta \mathrm{G}^{\circ}\left(\mathrm{kcal} \mathrm{mol}^{-1}\right)$ \\
\hline $\mathrm{Me}_{2} \mathrm{SnCl}_{2}\left(\mathrm{H}_{2} \mathrm{~L}\right)$ & $117.1 \pm 4.8$ & $331.8 \pm 16.3$ & $18.2 \pm 4.8$ \\
\hline $\mathrm{Et}_{2} \mathrm{SnCl}_{2}\left(\mathrm{H}_{2} \mathrm{~L}\right)$ & $107.6 \pm 5.4$ & $335.4 \pm 18.2$ & $15.1 \pm 5.3$ \\
\hline $\mathrm{Ph}_{2} \mathrm{SnCl}_{2}\left(\mathrm{H}_{2} \mathrm{~L}\right)$ & $104.7 \pm 5.8$ & $308.7 \pm 19.9$ & $13.1 \pm 5.8$ \\
\hline
\end{tabular}

Table 4 shows that the formation constant of complexes undergo a regular decrease from $\mathrm{Me}_{2} \mathrm{SnCl}_{2}\left(\mathrm{H}_{2} \mathrm{~L}\right), \mathrm{Et}_{2} \mathrm{SnCl}_{2}\left(\mathrm{H}_{2} \mathrm{~L}\right)$ to $\mathrm{Ph}_{2} \mathrm{SnCl}_{2}\left(\mathrm{H}_{2} \mathrm{~L}\right)$. This order might return to the importance of steric parameters on stability of complexes. For example, at $20{ }^{\circ} \mathrm{C}$ we have the following order of the formation constants: $\mathrm{Me}_{2} \mathrm{SnCl}_{2}\left(\mathrm{H}_{2} \mathrm{~L}\right)>\mathrm{Et}_{2} \mathrm{SnCl}_{2}\left(\mathrm{H}_{2} \mathrm{~L}\right)>\mathrm{Ph}_{2} \mathrm{SnCl}_{2}\left(\mathrm{H}_{2} \mathrm{~L}\right), 3.46>2.91>$ 2.64. The $\log \mathrm{K}$ values decreased with rising temperature, it shows that reactions under investigations have exothermic characteristics.

The values of $\Delta \mathrm{H}^{\circ}, \Delta \mathrm{G}^{\circ}$, and $\Delta \mathrm{S}^{\circ}$, are negative for these complexes. Generally, negative values of $\Delta \mathrm{H}^{\circ}$ are assigned to the exothermic reactions and the $\Delta \mathrm{S}^{\circ}<0$ refers to association between donor and acceptor molecules (Table 4). A greater contribution of the $\Delta \mathrm{H}^{\circ}$ relative to the $\Delta \mathrm{S}^{\circ}$ leads to a negative value of the $\Delta G^{\circ}$ in the Equation (2):

$$
\Delta G^{\circ}=\Delta H^{\circ}-\mathrm{T} \Delta S^{\circ}
$$

Negative values for $\Delta G^{\circ}$ show that these complex formations are energetically favorable.

\section{Computational studies}

Calculations were performed using the Gaussian 98 system of codes [27]. For geometry optimization, starting structures of reactants $\mathrm{H}_{2} \mathrm{~L}$ and $\mathrm{R}_{2} \mathrm{SnCl}_{2}$ as well as products $\left[\mathrm{R}_{2} \mathrm{SnCl}_{2}\left(\mathrm{H}_{2} \mathrm{~L}\right)\right]$ were fully optimized at $\mathrm{HF} / 3-21 \mathrm{G}^{*}$. Considering size of under investigation complexes and our calculation tools this level seems suitable for our purpose. Harmonic vibrational frequency calculations at $\mathrm{HF} / 3-21 \mathrm{G}^{*}$ level confirmed the structures as minima and enabled the evaluation of zero point energies (ZPE). The stabilization energy of products was defined as total energy corrected for ZPE of products minus reactants: $S E=E\left[R_{2} \operatorname{SnCl}_{2}\left(\mathrm{H}_{2} \mathrm{~L}\right)\right]$ $\left(\mathrm{E} \mathrm{H}_{2} \mathrm{~L}+\mathrm{E} \mathrm{R}_{2} \mathrm{SnCl}_{2}\right)$.

For each complex two structures were considered. In the first structure the $\mathrm{R}$ groups occupied equatorial positions, while in the second one $\mathrm{R}$ groups were axial. According to our theoretical calculations predicted stabilization energies of axial and equatorial structures of 
$\mathrm{Me}_{2} \mathrm{SnCl}_{2}\left(\mathrm{H}_{2} \mathrm{~L}\right)$ are -25.79 and $-20.12 \mathrm{kcal} \mathrm{mol}^{-1}$, respectively. Similarly, predicted stabilization energies for axial and equatorial structures of $\mathrm{Et}_{2} \mathrm{SnCl}_{2}\left(\mathrm{H}_{2} \mathrm{~L}\right)$ adducts are -26.27 and -19.51 kcal.mol ${ }^{-1}$. These results show that presence of $\mathrm{R}$ groups at axial positions leads to more stability of complexes. Less steric crowding in structures with $\mathrm{R}$ groups at axial positions probably lead to their greater stability. Another parameter that may help to greater stability of axial structure is possibility of hydrogen bonding interaction between NOH group of oxime with $\mathrm{Cl}$ atoms of organotin. However the $\mathrm{HF} / 3-21 \mathrm{G}^{*}$ is not a sophisticated level for study of hydrogen bonding but optimized structures showed that axial isomers with $\mathrm{H}$... Cl distances smaller than $2.4 \AA$ have better conditions for formation of such hydrogen bond interactions.

\section{CONCLUSIONS}

The synthesis and physical properties of a series of diorganotin(IV) dichloride complexes with $(2 \mathrm{H})-1,4-$ benzothiazine-2,3-(4H)-dione dioxime are described. The ligand behave as a bidentate fashion towards to tin(IV). The $\mathrm{X}$-ray crystalographic data of ligand is given. The $\left[\mathrm{R}_{2} \mathrm{SnCl}_{2}\left(\mathrm{H}_{2} \mathrm{~L}\right)\right]$ compounds were characterized using IR, MS, UV-Vis, and ${ }^{1} \mathrm{H}$ NMR methods. Theoretical calculations at the $\mathrm{HF} / 3-21 \mathrm{G}^{*}$ level was used to determine more stable structure. Thermodynamic stability of $\left[\mathrm{R}_{2} \mathrm{SnCl}_{2}\left(\mathrm{H}_{2} \mathrm{~L}\right)\right]$ complexes are in the order: $\left[\mathrm{Me}_{2} \mathrm{SnCl}_{2}\left(\mathrm{H}_{2} \mathrm{~L}\right)\right]>$ $\left[\mathrm{Et}_{2} \mathrm{SnCl}_{2}\left(\mathrm{H}_{2} \mathrm{~L}\right)\right]>\left[\mathrm{Ph}_{2} \mathrm{SnCl}_{2}\left(\mathrm{H}_{2} \mathrm{~L}\right)\right]$.

\section{REFERENCES}

1. Arkis, E. in Tin Chemistry: Fundamentals Frontiers, and Applications, Gielen, M.; Davies, A.; Pannell, K.; Tiekink, E. (Eds.), Wiley: West Sussex; 2008; p 312.

2. De Lima, G.M. in Tin Chemistry: Fundamentals Frontiers, and Applications, Gielen, M.; Davies, A.; Pannell, K.; Tiekink, E. (Eds.), Wiley: West Sussex; 2008; p 285.

3. Lacroix, P.G.; Farfán, R. in Tin Chemistry: Fundamentals Frontiers, and Applications; Gielen, M.; Davies, A.; Pannell, K.; Tiekink, E. (Eds.), Wiley: West Sussex; 2008; p 351.

4. Otera, J.; Biesemans, M.; Pinoie, V.; Poelmans, K.; Willem, R.; Blank, W.J.; Hessell, E.T.; Kinart, W.J.; Kinart, C.M. in Tin Chemistry: Fundamentals Frontiers, and Applications, Gielen, M.; Davies, A.; Pannell, K.; Tiekink, E. (Eds.), Wiley, West Sussex; 2008; p 667.

5. Fan, B.; Li, H.; Fan, W.; Zhang, J.; Li, R. Appl. Catal. A: Gen. 2010, 372, 94.

6. Davies, A.G. J. Chem. Res. 2010, 181.

7. Pettinari, C.; Marchetti, F. in Tin Chemistry: Fundamentals Frontiers, and Applications, Gielen, M.; Davies, A.; Pannell, K.; Tiekink, E. (Eds.), Wiley, West Sussex; 2008; p 454.

8. Despaigne, A.A.R.; Vieira, L.F.; Mendes, I.C.; da Costa, F.B.; Speziali, N.L.; Beraldo, H. J. Braz. Chem. Soc. 2010, 21, 1247.

9. Mendes, I.C.; Costa, F.B.; De Lima, G.M.; Ardisson, J.D.; Garcia-Santos, I.; Castineiras, A.; Beraldo, H. Polyhedron 2009, 28, 1179.

10. Eng, G.; Song, X. in Tin Chemistry: Fundamentals Frontiers, and Applications, Gielen, M.; Davies, A.; Pannell, K.; Tiekink, E. (Eds.), Wiley, West Sussex; 2008; p 430.

11. Siddiqi, K.S.; Khan, S.; Shahab, Nami, A.A. J. Inclu. Phen. Mac. Chem. 2006, 55, 359.

12. Win, Y.F.; Teoh, S.G.; Tengku-Muhammad, T.S.; Sivasothy, Y.; Ha, S.T. Am. J. Appl. Sci. 2010, 7, 301 .

13. Win, Y.F.; Teoh, S.G.; Tengku-Muhammad, T.S.; Ha, S.T.; Sivasothy, Y. Australian J. Basic Appl. Sci. 2010, 4, 1383.

14. Sen, A.; Chaudhuri, T.K. Exp. Oncol. 2009, 31, 22.

15. Cheremisinoff, N.P.; Rosenfeld, P.E. Handbook of Pollution Prevention and Cleaner Production, Elsevier: Amsterdam; 2010. 
16. Rehman, W.; Balocha, M.K.; Badshah, A. J. Braz. Chem. Soc. 2005, 16, 827.

17. Gleeson, B.; Claffey, J.; Ertler, D.; Hogan, M.; -Bunz, H.M.; Paradisi, F.; Wallis, D.; Tacke, M. Polyhedron 2008, 27, 3619.

18. Kakanejadifard, A.; Zabardasti, A.; Ghasemian, M.; Niknam, E. J. Coord. Chem. 2008, 61, 1820.

19. Zabardasti, A.; Kakanejadifard, A.; Amani, S. and Salehnassaje, M. Bull. Chem. Soc. Jpn. 2008, 81, 1072.

20. Armarego, L.F.W.; Chai, C.L.L.; Purification of Laboratory Chemicals, 5th ed., Butterworth-Heinemann: London; 2003.

21. Leggett, D.J. Computational Methods for the Determination of Formation Constant, Plenum Press: New York; 1985.

22. Sheldrick, G.M. SHELXTL v. 5.10, Structure Determination Software Suite, Bruker AXS: Madison, Wisconsin, USA; 1998.

23. Casas, J.S.; Sanchez, A.; J Sordo, V.A.; Lopez, Castellano, E.E Inorg. Chim. Acta 1994, $216,169$.

24. Willer, R.L.; Moore, D.W. J. Org. Chem. 1985, 50, 5123.

25. Jain, V.K.; Clark, H.C; Mehrotra, R.C.; Singh, B.P.; Srivastava, G.; Birchall, T. J. Organomet. Chem. 1985, 279, 385.

26. Iskander, M.F.; Labib, L.; Nour, M.M.Z.; Tawfik, M. Polyhedron 1989, 8, 2755.

27. Frisch, M.J.; Trucks, G.W.; Schlegel, H.B.; Scuseria, G.E.; Robb, M.A.; Cheeseman, J.R.; Montgomery, J.A.; Vreven, T.; Kudin, K.N.; Burant, J.C.; Millam, J.M.; Iyengar, S.S.; Tomasi, J.; Barone, V.; Mennucci, B.; Cossi, M.; Scalmani, G.; Rega, N.; Petersson, G.A.; Nakatsuji, H.; Hada, M.; Ehara, M.; Toyota, K.; Fukuda, R.; Hasegawa, J.; Ishida, M.; Nakajima, T.; Honda, Y.; Kitao, O.; Nakai, H.; Klene, M.; Knox, J.E.; Hratchian, H.P.; Cross, J.B.; Adamo, C.; Jaramillo, J.; Gomperts, R.; Stratmann, R.E.; Yazyev, O.; Austin, A.J.; Cammi, R.; Pomelli, C.; Ochterski, J.W.; Ayala, P.Y.; Morokuma, K.; Voth, G.A.; Salvador, P.; Dannenberg, J.J.; Zakrzewski, V.G.; Dapprich, S.; Daniels, A.D.; Strain, M.C.; Farkas, O.; Malick, D.K.; Rabuck, A.D.; Raghavachari, K.; Foresman, J.B.; Ortiz, J.V.; Cui, Q.; Baboul, A.G.; Clifford, S.; Cioslowski, J.; Stefanov, B.B.; Liu, G.; Liashenko, A.; Piskorz, P.; Komaromi, I.; Martin, R.L.; Fox, D.J.; Keith, T.; Al-Laham, M.A.; Peng, C.Y.; Nanayakkara, A.; Challacombe, M.; Gill, P.M.W.; Johnson, B.; Chen, W.; Wong, M.W.; Gonzalez, C.; Pople, J.A. Gaussian 98, revision A.6, Gaussian, Inc.: Pittsburgh, PA; 1998. 